\title{
A study on the training and education of inspectors to prevent, deter and eliminate illegal, unreported and unregulated (IUU) fishing in Turkey
}

\section{Raziye Tanriverdi ${ }^{1^{*}}$ (D) \\ ${ }^{1}$ Turkish Coast Guard Command, Coast Guard Antalya Group Command, 07070 Sarısu, Konyaaltı, Antalya, Turkey}

\begin{tabular}{|c|c|}
\hline A R T I C L E & A B S T R A C T \\
\hline & \multirow{11}{*}{$\begin{array}{l}\text { The aim of this study was to examine present training conditions of inspectors and the } \\
\text { current situation in Turkey to prevent, deter and eliminate IUU fishing within the scope of } \\
\text { the training of qualified inspectors which was one of port states' duties according to the } \\
\text { PSMA to Prevent, Deter and Eliminate IUU Fishing. In Turkey, the inspectors of the } \\
\text { Ministry of Agriculture and Forestry and the Command of Coast Guard had sufficient } \\
\text { training according to the Annex-E of Article } 17 \text { of the PSMA to Prevent, Deter and } \\
\text { Eliminate IUU Fishing. The trainings related to the provisions stated in the Annex-E of } \\
\text { Article } 17 \text { of the PSMA to Prevent, Deter and Eliminate IUU Fishing should be planned or } \\
\text { necessary studies should be carried out by the Ministry of Agriculture and Forestry for } \\
\text { authorized institutions and organizations other than the Ministry of Agriculture and } \\
\text { Forestry and the Coast Guard Command. Legal arrangements should be made on the } \\
\text { training of inspectors in order to prevent IUU fishing in the Fisheries Law. }\end{array}$} \\
\hline Received: 23.08 .2021 & \\
\hline Received in revised form: 08.10 .2021 & \\
\hline $\begin{array}{l}\text { Accepted: } 08.10 .2021 \\
\text { Available online: } 21.12\end{array}$ & \\
\hline & \\
\hline $\begin{array}{l}\text { Keywords: } \\
\text { PSMA }\end{array}$ & \\
\hline IUU Fishing & \\
\hline Inspector & \\
\hline Training & \\
\hline Education & \\
\hline & \\
\hline
\end{tabular}

Please cite this paper as follows:

Tanriverdi, R. (2021). A study on the training and education of inspectors to prevent, deter and eliminate illegal, unreported and unregulated (IUU) fishing in Turkey. Marine Science and Technology Bulletin, 10(4), 376-387. https://doi.org/10.33714/masteb.985671

\section{Introduction}

Illegal, unreported and unregulated fishing (IUU fishing) is a global problem affecting both exclusive economic zones and the high seas (Boto et al., 2009). In the context of the Code of Conduct for Responsible Fisheries and its overall objective of sustainable fisheries, the issue of IUU fishing in world fisheries is of serious and increasing concern. IUU fishing undermines efforts to conserve and manage fish stocks in all capture fisheries (FAO, 2001). To prevent IUU Fishing on the national and international level, in 2001, the Food and Agriculture Organization of the United Nations (FAO, 2021) signed an International Plan of Action to Prevent, Deter and Eliminate IUU Fishing within the framework of the code of conduct for responsible fisheries (FAO, 2001).

* Corresponding author

E-mail address: rtanriverdi@sg.gov.tr (R. Tanrıverdi) 
The Agreement on Port State Measures (PSMA) to Prevent, Deter and Eliminate IUU Fishing was approved by the FAO Conference at its Thirty-sixth Session on 22 November 2009 (FAO, 2009). Turkey has been part/has deposited to "the PSMA to Prevent, Deter and Eliminate IUU Fishing" on 9 November 2010 (FAO, 2021). Turkey signed this Agreement as the 18th country together with 23 countries which are United States of America, European Union (EU)-Member Organization, France, Russian Federation, Canada, Australia, New Zealand, Kenya, Angola, Brazil, Chile, Iceland, Indonesia, Norway, Samoa, Uruguay, Sierra Leone, Gabon, Ghana, Benin, Peru and Mozambique (FAO, 2009). Besides, the EU candidate membership period of Turkey is still in progress (EC, 2021). The PSMA to Prevent, Deter and Eliminate IUU Fishing came into force with the Official Gazette of the EU numbered L 191/3 and dated 22.07.2011 (EU, 2011).

Port states duties are determined in the PSMA to Prevent, Deter and Eliminate IUU Fishing. The training and education of qualified inspectors are among port state duties. Each Party shall ensure that its inspectors are properly trained taking into account the guidelines for the training of inspectors in Annex E of the 17th Article of the agreement (EU, 2011; FAO, 2021).

Elements of a training programme for port State inspectors according to Annex E should include at least the following areas: Ethics; Health, safety and security issues; Applicable national laws and regulations, areas of competence and conservation and management measures of relevant Regional Fisheries Management Organizations, and applicable international law; Collection, evaluation and preservation of evidence; General inspection procedures such as report writing and interview techniques; Analysis of information, such as logbooks, electronic documentation and vessel history (name, ownership and flag State), required for the validation of information given by the master of the vessel; Vessel boarding and inspection, including hold inspections and calculation of vessel hold volumes; Verification and validation of information related to landings, transhipments, processing and fish remaining onboard, including utilizing conversion factors for the various species and products; Identification of fish species, and the measurement of length and other biological parameters; Identification of vessels and gear, and techniques for the inspection and measurement of gear; Equipment and operation of Vessel Monitoring System (VMS) and other electronic tracking systems; and Actions to be taken following an inspection (FAO, 2021; EU, 2011).

There are very few studies about the IUU fishing in Turkey (Öztürk, 2013; Öztürk, 2015; Göktürk \& Deniz, 2017). The aim of this study is to examine present training conditions of inspectors in Turkey to prevent, deter and eliminate illegal, unreported and unregulated fishing within the scope of the training of qualified inspectors which is one of port states' duties according to "the PSMA to Prevent, Deter and Eliminate IUU Fishing".

\section{Materials and Methods}

National and international legislations were examined. The activities of inspector institutions in Turkey in the field of fisheries inspection were investigated. Written and oral interviews were conducted with the auditors or inspector institutions.

\section{Results}

\section{Organizations and Institutions Authorized for the}

\section{Prevention of Illegal, Unregistered, and Irregular}

\section{Fishing in Turkey}

In accordance with the Presidential Decree No: 1 on the Organization of the Presidential the Protection Services of Fishery Products is executed by the Directorate General of Fisheries and Aquaculture under the Ministry of Agriculture and Forestry (Anonymous, 2018), by the Fisheries and Aquaculture Branch Directorate in provinces (MAF, 2021a). The control of the fisheries in seas and inland waters in Turkey is performed by the organizations and institutions which are also stated in the Fishery Law.

According to the 33rd Article of the Fishery Law, the personnel appointed for the protection and control of fishery products, seas and inland waters at the Ministry of Agriculture and Forestry and institutions regarding fishery as well as the associates of Police, Gendarme, Coast Guard, Customs and Forestry Enforcement Institution, Municipal police forces, Guardians, Wardens Attached to Public Legal Entities, Headmen or Board of Elders of the village in places where no police and gendarme stations exist are all authorized for the inspection of fishery at seas and inland waters. Due to the Fishery Law and the prohibitions based on this Law, these organizations and institutions are authorized and charged with the tasks of taking the minutes of crimes which are in the scope of this Law, seizing the caught fishery products and the fishing gears used during the crime, imposing administrative fines within the scope of their authority (Anonymous, 1971).

According to the 34th Article of the Fishery Regulation, the superior local administrative chief has been authorized for 
imposing administrative fines for illegal fishing. Local Authorities can assign their fine rights to organizations or institutions having inspection competence on condition that they declare beforehand (Anonymous, 1995).

As per the 35th Article of the Fishery Regulation, the commanders of the Coast Guard boats are authorized to give administrative fines in seas within the Turkish Territorial Waters and Exclusive Economic Zone, the Istanbul and Dardanelles Straits and in ports and gulfs (Anonymous, 1995).

\section{Ministry of Agriculture and Forestry}

Within the 412th article of the Presidential Decree No: 1 on the Organization of the Presidential the Directorate General of Fisheries and Aquaculture is also stated among the service units of the Ministry (Anonymous, 2018). Within the 416th Article of the Presidential Decree No: 1 Law, the tasks of the Directorate General of Fisheries and Aquaculture are specified and in the 1-d clause of this article the task is specified as "Fostering fisheries and the production sources of fishery and raising productivity, carrying out inspections (Anonymous, 2018).

Within the first clause of the Article 33 of the Fishery Regulation, it is stated that "the Ministry inspects and controls fishery product producers, merchants, industrialists, tradesmen, importers and exporters who deal with these products and their workplaces, fish markets, auction places, fishery processing and assessment facilities, the products obtained from these places, regions of fishery products, ports, shelters, landing places and the capture tools of fishers and carries out the necessary procedures according to the legislation (Anonymous, 1995).

The authorized personnel of the Ministry of Food, Agriculture and Livestock is assigned to inspect fisherman shelters and their superstructures and to examine and control the management and control matters, any kind of document and record and carries out the necessary procedures as per Article 20 of the Regulation on the Fisherman Shelter (Anonymous, 1996).

Personnel trained in the field of fisheries work in the Directorate General of Fisheries and Aquaculture and Branch Directorates of the Ministry of Agriculture and Forestry. Inservice Training Programs are prepared in line with the decisions taken by the Ministry of Agriculture and Forestry by the Education Board and the proposals of the Central Service Units of the Ministry (MAF, 2021b). In-Service Training activities are carried out through the Personnel Training System with a transparent, traceable and evaluable method in cooperation with the Central and Provincial Organizations, Universities and other public institutions and organizations (MAF, 2021b)

Distribution of illegal fishing activities determined by the Ministry of Agriculture and Forestry by ratios between 2012 and 2015 (9-month period) are given in Figure 1 (Atalay, 2015).

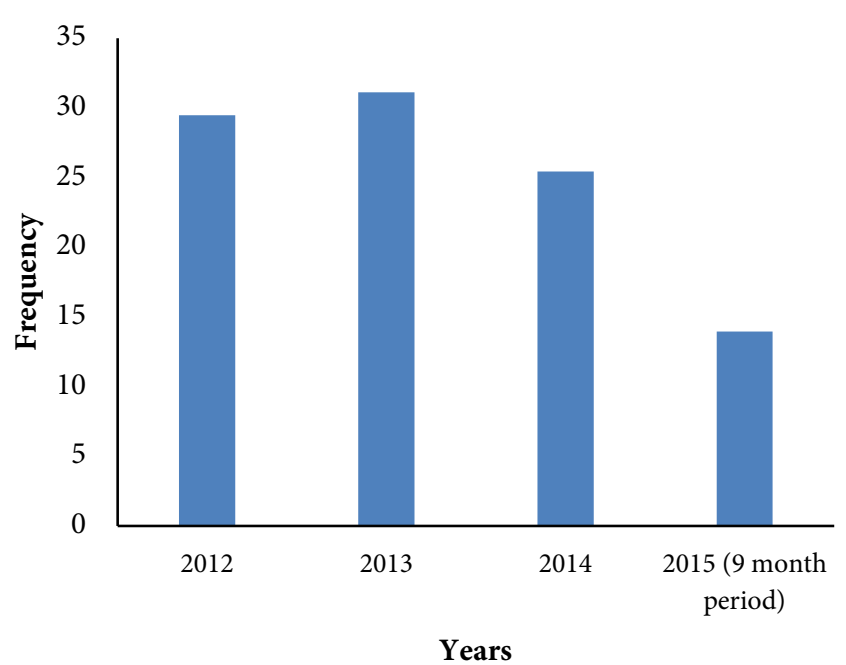

Figure 1. The variation of IUU fishing activities between 2012 and 2015 (9-month period) (Atalay, 2015).

\section{General Directorate of Security}

As per the 1st Article of the Security Affairs Law, the Minister of Interior is responsible for the countries' general security and public order (Anonymous, 1937). The Minister of Interior performs these tasks by means of the General Security Directorate and Gendarmerie General Command acting within the circle of their own laws and when necessary, it utilizes from the army with the decision of the Cabinet (Anonymous, 1937).

As per the 3rd Article of the Security Affairs Law, the police organization; is divided into two sections as general (these are the police and gendarmerie which are armed forces) and special the general law enforcement (Anonymous, 1937). Special law enforcement; are the law enforcement forces except for the general law enforcement which carry out determined duties and which are founded as per intentional laws (Anonymous, 1937). Special law enforcement, Forest Enforcement Officers, Customs Enforcement Officers and Municipal Police Officers, etc. can be expressed (Akman \& Bayram, 2018; Arslan, 2018). The gendarmerie and the special law enforcement agencies are liable to their own laws and the law enforcement is liable to the provisions of this law (Anonymous, 1937). The liaison, communication and working methods of the gendarmerie and special police and other law enforcement forces are determined by regulations (Anonymous, 1937). 
According to the 4th Article of the Security Affairs Law, the security organization is an armed force which is divided into two as uniformed forces and civilian forces (Anonymous, 1937). As per the 5th Article of this Law uniformed police forces consist of units with or without vehicles (Anonymous, 1937). Police units with vehicle are equipped with mounted means or motor vehicles or bicycles and other living or lifeless vehicles (Anonymous, 1937).

According to the 8th Article of the Security Affairs Law, the police is divided into administrative political and judicial parts and as per the 9th Article, the administrative police is responsible for the procurement of public order (Anonymous, 1937).

As per the 3rd Article of the Regulation on the Tasks of the Gendarmerie and Police in Provinces Districts and SubDistricts and their Authority Form and Interactions, the Area within the Municipality Borders of the Provinces and Districts is under the responsibility of the police, the area outside the municipality borders of the provinces and districts is under the responsibility of the Gendarmerie (Anonymous, 1961). Considering the personnel, tools and service requirements of the law enforcement certain areas outside the municipality borders can be determined within the area of responsibility of the police; some areas which are within the municipality borders but are far from residential areas can be determined within the area of responsibility of the Gendarmerie (Anonymous, 1961).

As per the 2nd Article of the Law Regulating the Tasks and Authorities of the Police, one of the tasks of the police related to security is to prevent illegal activities which are not complying with Laws, By-laws, government orders and the public order within the framework of the provisions of this law hereby (Anonymous, 1934).

The in-service training of the Turkish Police is given by the General Directorate of Security Training Department, and the entire pre-service training is provided by the training units called Police Chiefs Training Centre, Police Vocational School, Police Vocational Training Centre (GDS, 2021).

The duty types of the General Directorate of Security consist of Traffic Police, Marine Police, Motorcycle Police, Air Police, Juvenile Police, Anti-Terrorism, Fight Against Smuggling and Organized Crime, Riot Force and Special Operations (GDS, 2021).

The Marine Police is the police force responsible for ports, gulfs and inland waters. It is the unit responsible for the administrative and judicial procedures at sea on behalf of the security agency (GDS, 2021).
The maritime police carried out controls and inspections to prevent poaching, especially in the coastal waters of Istanbul, Izmir and Tekirdağ provinces. It was seen that the controls and inspections were carried out in coordination with the Ministry of Agriculture and Forestry (ISPAFD, 2020; AA, 2021; MM, 2021).

The police inspected showrooms selling fishing equipment to hinder the production and sale of tirıvirı (local name in Turkish) and parachute (a piece of fish line net which is attached to a fishing line to catch fish) with the personnel of the Ministry of Agriculture and Forestry (HC, 2010; HC, 2014; IASFA, 2019a).

According to need, Fishery Law, fishery gears and methods, fisheries management, landing points, shelters, wholesale and retail outlets, etc. trainings were given to the Marine Police, tasked with IUU Fishing preventions, by the Istanbul University Faculty of Fisheries, Istanbul and Izmir Directorates of Agriculture and Forestry (HC, 2015; IPAFD, 2015; IASFA, 2019b).

\section{The Gendarmerie General Command}

Except for the administrative, judicial and military tasks of the Gendarmerie stipulated in the 7th Article of the Law on the Organization, Tasks and Authorities of the Gendarmerie other Duties of the Gendarmerie is the execution of other laws and statute provisions and resolutions and orders of this laws (Anonymous, 1983a).

The Gendarmerie Command is attaching great importance to protect the environmental and ecological balance and if possible, to rehabilitate the damaged environment. Therefore, it has founded 41 Environmental Protection Teams to work within the structure of the Directorates of Public Order of the Gendarmerie Command of 38 Provinces in order to make research on maritime pollution, air pollution and solid waste pollution and their resources under their responsibility and to send the results of the researches as reports to the concerned institutions to get the necessary procedures done (APGC, 2021; GGC, 2021).

The environment protection teams; consist of the Team Commander, Team Deputy Commander and Environmental and Wildlife Conservation Specialist. One of the duties of the Environment Protection Teams is to control activities violating the Fishery Law and to determine offences by using technical tools such as video and photo cameras in situations which are against the legislation (APGC, 2021; GGC, 2021).

To prevent IUU fishing, the personnel who will be assigned in the Environment Protection Teams should primarily get 
theoretical and operative training in the Gendarmerie General Command on fishery legislation.

\section{Command of Coast Guard}

It is specified in the 4th Article of the Command of Coast Guard Law that it is under the responsibility of the Command of Coast Guard to seize people violating the Fishery Law to monitor and prevent them, and to seize the offenders and follow necessary proceedings (Anonymous, 1982).

The Command of Coast Guard personnel undergoes a training provided by the Coast Guard School Command in order to fulfil and carry out fishing controls and inspections successfully within the authority entrusted by the Fishery Law and Command of Coast Guard Law.

The Fishery Course contains the following topics; the General Assessment on the Fishery in Turkey, Commercially Important Species that are caught in Turkish waters (identification of fish species, the measurement of length and other biological parameters etc.), Fishery Gears and Fishing Methods (with the inclusion of techniques for the inspection and measurement of gear), IUU fishing, Provisions of Practice and Fining Procedures, Fishery Licenses, Prohibitions Related to Fishing And Law Enforcement Provisions, Fishery Production and Judicial Legislation, VMS, Fishery Information System, The Problems during the Practice of Fishery Legislation.

In the fishery lesson which is provided in the scope of the trainings and courses within the structure of the Coast Guard School Command, practical training is very important. Within this scope, "A Protocol on the Practical Training Principals" has been signed between the Coast Guard Education and Training Command and the Akdeniz University.

In the lectures video demonstrations are provided on capturing and fishing tools. Existing fishery and fishing gears in the Fisheries Port and Fisher's Auction are examined in the fishery Laboratory. For some issues, external conference experts are invited from the relevant institutions/universities.

Useful publications for the fishery lessons are provided periodically for the Coast Guard Education and Training Command personnel. The Coast Guard Magazine also publishes studies related to fishery.

In the application process of the fishery legislation the administrative acquired and cancelled sentences are examined in the lessons, the legislation amendments are followed, the photos, Compact Disc's and proceedings change of ownership by the Coast Guard Boat Commanders and which will be used as evidence for violating Fishery Law are examined in the lessons, the concerned proceedings related to case studies are filled by the trained staff and how to behave in similar situations is taught to the cadets.

"The Fishery Booklet" and "Maritime Fishing Gears and Methods" will be useful on the fishery for the Coast Guard personnel are prepared by the Command of Coast Guard

Distribution of illegal fishing activities determined by the Command of Coast Guard by ratios between 2016 and 2021 (6month period) are given in Figure 2 (CGC, 2021).

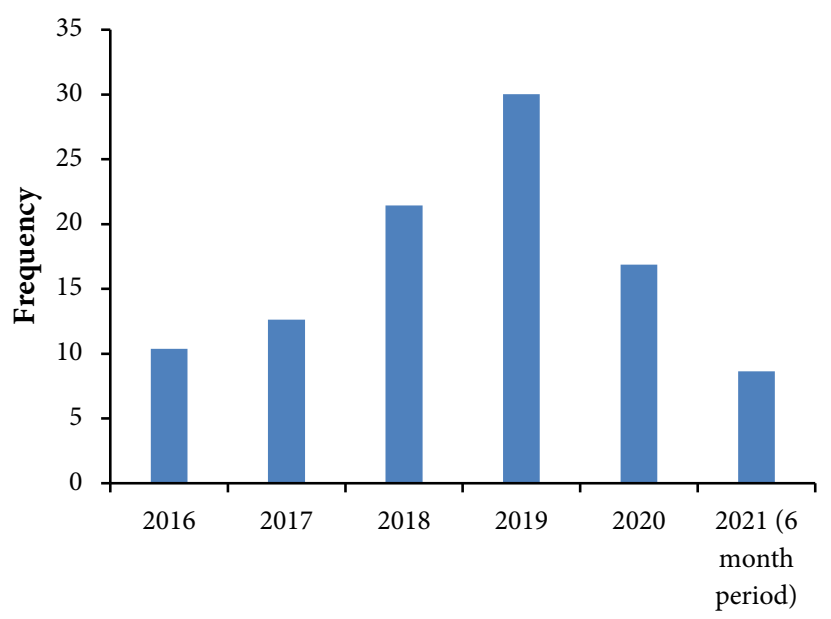

Years

Figure 2. The variation of IUU fishing activities between 2016 and 2021 (6-month period) (CGC, 2021).

\section{Directorate General of Customs Enforcement}

According to Article 72/L of the Customs Regulation, the Ministry of Commerce of the Republic of Turkey determines the procedures and principles regarding customs surveillance and inspection in loading, transportation and unloading by all sea vehicles belonging to real or legal persons between ports and piers in the Customs Territory of Turkey (Anonymous, 2009).

Customs Enforcement Officers is a law enforcement agency working under the Ministry of Trade of the Republic of Turkey, and its primary duty is to combat smuggling (RTMT, 2021). In order to become a Customs Enforcement Officer, it is necessary to have a bachelor's degree and to be successful in the written proficiency exam and interview exams to be held after the basic education and internship phase. Customs Enforcement Officers receive training on fisheries law (Soydan \& Ünal, 2019; HT, 2021; KN, 2021)

\section{Directorate General of Forestry}

According to the 20th and 30th articles of the Regulation on the Duties and Working Principles of Forest Enforcement Officers, Forest Enforcement Officers are authorized to apply the fisheries law for those caught from lakes and streams in the 
forest without obtaining permission from the forest administration (MAFF-FGD, 1996).

As per the 4th Article of the Forest Law, forests are categorised with regard to possession and administration as A) State forests; B) Forests of public establishments run by private corporations; C) Private forests. In terms of quality and character forests are divided as: A) Protection forests; B) National parks; C) Production forests (Anonymous, 1956).

As per the 6th Article of the Forest Law, any kind of work related to state forests and forests regarded as state forests are carried out by the General Directorate of Forests (Turkey, 1956). All forests, belonging to others but the state, are subject to the control of the General Directorate of Forests (Anonymous, 1956).

As per the 10th Article of the Regulation Forests Regarding Special Forests and Authorized Public Institutions, Special Forests and Forest regarding Authorized Public Institutions are operated and administered under the control and supervision of the forest administration (Anonymous, 2016).

In accordance with the 16th Article of National Parks Law, within the areas which are in the scope of this law, protection services and pursuing offences is provided by the Forest Enforcement Officers based on the provisions related to the pursuit of offences in the fifth section and fourth part of the Forest Law (Anonymous, 1983b).

According to Article 12 of the Regulation on Appointment and Relocation of Forest Enforcement Officers, Forest Enforcement Officers are required to graduate from the departments of Forestry and Forest Products, Forest Management, Forestry, Forest Products, Non-Wood Forest Products, Sapling Cultivation, Sapling Growing, Sapling and Seedling, Pruning and Grafting, Hunting and Wildlife, Hunting and Wildlife one of the associate degree programs of higher education institutions (Anonymous, 2011).

It was determined that the Forest Enforcement Officers did not get any in service training on inspection of fishery.

\section{Municipal Police Forces}

As per the 7th Article of the Metropolitan Municipality Law, one of the duties of the Metropolitan Municipality is to perform constabulary duties within their areas of responsibility (Anonymous, 2004a).

As per the 14th Article of the Municipality Law, performing constabulary services are under the responsibility of the Municipality (Anonymous, 2005).

In accordance with the 51st Article of the Municipality Law, the Municipal Police is responsible for the peace, health and order of the region and therefore enforces orders and bans taken the Municipality Assembly and executes the envisioned penalties and other sanctions for those who violate these laws (Anonymous, 2005).

As per the 10th Article of the Regulation on the Municipal Police Force, it is under the responsibility of the Municipal Police to use its authority and perform its tasks specified in bylaws and regulations in order to ensure the order within the Municipality borders and to preserve the peace and health of the people living there (Anonymous, 2007).

As per the 11th Article of the Regulation on the Municipal Police Force, the Municipal Police can enter public places, perform necessary controls, can demand documents from the owner or operator (of a business enterprise) and can write a record of these people within the borders of the municipality in order to fulfil its tasks granted by laws, regulations by-laws and authorized municipal organs (Anonymous, 2007).

According to Article 13 of the Regulation on the Municipal Police Force, it is necessary to be at least a high school graduate or equivalent to become a Municipal Police Officer (Anonymous, 2007). Depending on the need, it is required to have an associate degree and a bachelor's degree in subjects such as law, environment and food in order to be a Municipal Police Personnel (AMM, 2021).

According to article 28 of the Regulation on the Municipal Police Force, the basic and technical training of the personnel of the municipal police is carried out in cooperation with public institutions and organizations with training centres, relevant departments of universities or relevant non-governmental organizations when necessary (Anonymous, 2007). Based on the demand Municipal Police Forces were given Fisheries Inspection Training on retail outlets, fishing and length bans by Istanbul Agriculture and Forestry Directorates (BM, 2015; ISPAFD, 2015).

Guardians, Gatekeepers and Wardens Ground to Public Private Corporations and Members of the Council

\section{of Elderly}

In accordance with the 2nd Article of the Law for the Formation of Headmanship and Council of Elderly of Neighbourhoods in Cities and Towns, Headmanship and the Council of Elderly consist of one headmanship and four members. The Council has four auxiliary members (Anonymous, 1944). As per the 32nd Article of the Statute on Headmanship and Council of Elderly in Cities and Towns, the Headmanship and Council of Elderly is authorized to notify in 
writing one of the official veterinary institutions in the town or the nearest civilian administration as soon as possible in case of epidemic and contagious diseases which are specified in the Veterinary Services, Plant Health, Food and Feed Law; as per the Law on the Interdiction and Pursuit of Smuggling, the duties of the Headmanship and Council of Elderly are as follows: A) to inform in writing the head of the civilian administration responsible for preventing and following illegal activities, Customs and Monopoly Officers, head of the police, commissary or his deputies, the Commander of the Gendarmerie or his staff or Coast Guard Officers and members in coasts on activities stipulated as illegal by laws B) in places where there aren't any civilian administration members responsible for preventing and following illegal activities to prevent smuggling itself and inform Customs and Monopoly Officers and the head of the civilian administration, C) to attend searches in private houses suspected with concealing smuggled goods and in shops, stores and commercial houses, warehouses, storehouses, warehouse, inns, hotels, pensions, cinemas, theatres, casinos, coffeehouses, pubs, when they are not open to the public (Anonymous, 1945).

It was determined that the Headmanship and Council of Elderly did not get any in service training on inspection of fishery.

\section{Discussion}

In Turkey, the Ministry of Agriculture and Forestry is the responsible institution for the protection and control of fishery products. It had been determined that people who have been trained in aquaculture and fisheries work in the control and inspection of fishery products. It was determined that in-service training activities were carried out in a transparent, traceable and evaluable method in cooperation with Central and Provincial Organizations, Universities and other public institutions and organizations through the Personnel Training System.

The General Directorate of Security has the authority to control catch yields of fishery within its area of responsibility in Turkey. One of the duty types of the General Directorate of Security is the Marine Police. The Marine Police is the police force in ports, gulfs and inland waters. It was determined that the maritime police conducted controls and inspections to prevent illegal fishing. It was determined that the maritime police received training on fishery control according to the need.

In Turkey, it was detected that Environmental Protection Teams were established within the Gendarmerie General
Command in order to conduct research on marine pollution, air pollution and solid waste pollution and their sources under their responsibility, and to report the results of the research to the relevant institutions and take necessary actions. One of the duties of Environmental Protection Teams was to control activities against the Fisheries Law. It was determined that the person who would work in the Environmental Protection Teams should receive theoretical and operational training on environmental and fisheries legislation.

Within the scope of training and courses organized by the Coast Guard School Command, it had been determined that training is given on subjects such as Fish Species (identification of fish species, the measurement of length and other biological parameters etc.), Fishing Gears and Fishing Methods (with the inclusion of techniques for the inspection and measurement of gear), Fishery Legislation, Illegal Fishing Methods and European Union Fishery Policy, VMS, Fishery Information System in Turkey.

Customs Enforcement Officers is a law enforcement agency working under the Ministry of Trade of the Republic of Turkey. It was determined that Customs Enforcement Officers received training on fisheries law.

It was detected that the Forest Enforcement Officers, who had trained in the field of forestry and hunting and wildlife, working in the Forestry Organization, had not received any training on the control of fisheries in Turkey.

In Turkey, it was found that the basic and technical training of Municipal Police Personnel was carried out in cooperation with training centres and public institutions and organizations, relevant units of universities or, when necessary, relevant nongovernmental organizations. Fisheries Inspection Training was given to the municipal police teams by the Istanbul Agriculture and Forestry Directorates upon request.

It was determined that neighbourhood and village headmen had duties such as preventing and following issues regarding the health of animals and smuggling, informing the relevant institutions, and being present during searches in Turkey. It was found that Bolu Directorate of Agriculture and Forestry provided in-service training to Village and Neighbourhood Headmen on Pasture Law, inheritance and sales of agricultural lands, animal health and support. In addition, it was detected that trainings were organized on the subjects Animal Husbandry and Fishing, Source of Life, Village Law No. 442, etc. for the Neighbourhoods and Headmen by the Çorum Governorship.

In the forum on IUU Fishing held in South and East Africa (Mozambique, Angola, Comoros, France, Kenya, Madagascar, 
Maldives, Somali Tanzania, Food and Agriculture Organization etc.) in 2007, it was determined that the inspectors and observers have insufficiency in training and need to update their education (Limitada, 2007). In November 2010, the Regional Schedules of Action of Western Africa (Senegal), Caribbean (Belize), Central Africa (Libreville, Gabon), Eastern Africa (Kampala, Uganda), South Africa (Maputo, Mozambique) and Pacific (Honiara, Solomon Islands) the training need of inspectors, observers and legislation personnel was specified (Tarabusi, 2010; Mobiha, 2010; Purvis \& Mindjimba, 2010; Njifonjou, 2010; Grant, 2010; Sall, 2010). One of the results of the Report of the Workshop on Capacity Building of Developing States for Port State Measures and Catch Documentation Schemes of the Korea Republic held on 19-21 April 2011 was that the port state inspectors require adequate training (Tuna-org, 2011). Training and human capacity building was one of the topics agreed on at the FAO Regional Workshop on PSM to Combat IUU Fishing held in South Africa in 2008 for further action and cooperation in strengthening and harmonization of port state measures (FAO, 2008b). The subjects that were aimed to be developed within the scope of this subject were species identification, port state measures, measures against IUU fishing, VMS interpretation and Capacity development for legal expertise and skills (FAO, 2008b).

The first PSMA Inspectors Training Course was held in Vigo, Spain with the participation of twelve senior fisheries inspectors from Costa Rica, Ecuador, Panama and Peru in 2018 by FAO (FAO, 2018). FAO continued the capacity building trainings to implement PSMA in Guinea in 2019. Fifteen fisheries inspectors and seven additional government representatives from the Ministry of Fisheries, Coast Guard, Customs and Navy attended the training (FAO, 2019). Fish Force Academy was established to combat fishing crimes in South Africa. Similarly, the Australian government ran a capacity-building program among Fisheries Monitoring and Surveillance Officers across the Southeast Asian region. It was reported that Non-Governmental Organizations (NGOs) worked closely with coastal states in global geographies such as Italy, Gabon, Ghana, Namibia, Benin and Cape Verde to help combat IUU fishing (Wirajuda et al., 2019).

\section{Conclusion}

Turkey became a party to the "International Agreement on the Measures of the Port States for the Prevention of IUU Fishing" on the 9th of November 2010. According to the mentioned above agreement one of the responsibilities of port states is the training of high calibre inspectors. As per the agreement each party is authorized to provide the training of the inspectors in the country.

As per Article 5 with the title Integration and Coordination at the national level of the Agreement on the Measures of the Port States for the Prevention of IUU Fishing, each party integrated Port State measures with other measures to prevent, deter and eliminate IUU fishing and fishing related activities in support of such fishing, taking into account as appropriate the IPOA-IUU; and take measures to exchange information among relevant national agencies and to coordinate the activities of such agencies in the implementation of this Agreement (FAO,2009; EU, 2011).

Article 16 of the Fishery Law states that the Ministry of Agriculture and Forestry can plan training and education actions to improve the professional knowledge and experience of fishermen (Turkey, 1971). But the Fishery Law doesn't consist of anything regarding the training of inspectors. Besides, the integration of the training of inspectors should be provided within the scope of the 416th article of the Presidential Decree No: 1 .

In Turkey, the inspectors of the Ministry of Agriculture and Forestry and the Command of Coast Guard had sufficient training according to the Annex-E of Article 17 of the PSMA to Prevent, Deter and Eliminate IUU Fishing. The trainings related to the provisions stated in the Annex-E of Article 17 of the PSMA to Prevent, Deter and Eliminate IUU Fishing should be planned or necessary studies should be carried out by the Ministry of Agriculture and Forestry for authorized institutions and organizations other than the Ministry of Agriculture and Forestry and the Command of Coast Guard.

International Forums on IUU Fishing (CH, 2009; FCWC, 2011; NFDS, 2016; IUUW atch, 2017; CH, 2018; CH, 2020) and Global Fisheries Enforcement Training Workshops (FAO, 2007; FAO, 2008a; FAO, 2017; GFETW, 2021) were held. To prevent IUU Fishing on a national and international level it was evaluated that it will be beneficial to participate in workshops on the prevention of IUU Fishing and Global Applied Training Workshop and to coordinate planned and continuous workshops, seminars and symposiums between the inspecting organizations in Turkey on the prevention of IUU Fishing.

\section{Compliance With Ethical Standards}

\section{Conflict of Interest}

The author declares that there is no conflict of interest. 


\section{Ethical Approval}

For this type of study, formal consent is not required.

\section{References}

AA (www.aa.com.tr). (2021). Helicopter assisted poaching operation in Izmir. Retrieved on July 03, 2021 from https://www.aa.com.tr/tr/gundem/izmirde-helikopterdestekli-kacak-avcilik-operasyonu-/2289121

Akman, E., \& Bayram, T. (2018). Municipal police as private law enforcement force: A qualitative analysis of basic problems of municipal police in Isparta scale. Journal of the International Academy of Management, 1(3), 348356. https://doi.org/10.33712/mana.502176

AMM (Ankara Metropolitan Municipality). (2021). Purchase Announcement for the First Time Appointment. Official Gazette, 29 May 2021, Number: 31495. Retrieved on July 24, 2021 from https://www.resmigazete.gov.tr/ilanlar/eskiilanlar/2021 105/20210529-4-11.pdf

Anonymous. (1934). Law Regulating the Tasks and Authorities of the Police. Official Gazette of the Republic of Turkey, 14 July 1934, Number: 2751, Article 2.

Anonymous. (1937). Security Affairs Law. Official Gazette of the Republic of Turkey, 12 June 1937, Number: 3629, Articles 1, 3, 4, 5, 8 and 9.

Anonymous. (1944). Law for the Formation of Headmanship and Council of Elderly of Neighbourhoods in Cities and Towns. Official Gazette of the Republic of Turkey, 15 April 1944, Number: 5682, Article 2.

Anonymous. (1945). The Statute on Headmanship and Council of Elderly in Cities and Towns the Headmanship and Council of Elderly. Official Gazette of the Republic of Turkey, 26 April 1945, Number: 5991, Article 32.

Anonymous. (1956). Forest Law. Official Gazette of the Republic of Turkey, 08 September 1956, Number: 9402, Articles 4 and 6.

Anonymous. (1961). Regulation on the Tasks of the Gendarmerie and Police in Provinces, Districts and SubDistricts and their Authority Form and Interactions, the Area within the Municipality Borders of the Provinces and Districts. Official Gazette of the Republic of Turkey, 15 July 1961, Number: 10855, Article 3.

Anonymous. (1971). Fishery Law. Official Gazette of the Republic of Turkey, 04 April 1971, Number: 13799, Articles 16, 23, 26, 33 and 36.
Anonymous. (1982). Command of Coast Guard Law. Official Gazette of the Republic of Turkey, 13 July 1982, Number: 17753, Article 4.

Anonymous. (1983a). Law on the Organization, Tasks and Authorities of the Gendarmerie. Official Gazette of the Republic of Turkey, 12 March 1983, Number: 17985, Article 7.

Anonymous. (1983b). National Parks Law. Official Gazette of the Republic of Turkey, 11 August 1983, Number: 18132, Article 16.

Anonymous. (1995). Fishery Regulation. Official Gazette of the Republic of Turkey, 10 March 1995, Number: 22223, Articles 33, 34 and 35.

Anonymous. (1996). Regulation on the Fisherman Shelter. Official Gazette of the Republic of Turkey, 13 December 1996, Number: 22846, Article 20.

Anonymous. (2002). Bulk and Retail Sail Points of Fishery Regulation. Official Gazette of the Republic of Turkey, 19 June 2002, Number: 24790, Article 31.

Anonymous. (2004a). Metropolitan Municipality Law. Official Gazette of the Republic of Turkey, 23 July 2004, Number: 25531, Article 7.

Anonymous. (2004b). Regulation on the Production of Fishery. Official Gazette of the Republic of Turkey, 29 June 2004, Number: 25507, Article 23.

Anonymous. (2005). Municipality Law. Official Gazette of the Republic of Turkey, 13 July 2005, Number: 25874, Articles 14 and 51.

Anonymous. (2007). Regulation on Municipal Police Forces. Official Gazette of the Republic of Turkey, 11 April 2007, Number: 26490, Articles 10, 11, 13 and 28.

Anonymous. (2009). Customs Regulation. Official Gazette of the Republic of Turkey, 07 October 2009, Number: 27369 (Repeated), Article 72/L.

Anonymous. (2010a). The Veterinary Services, Plant Health, Food and Feed Law. Official Gazette of the Republic of Turkey, 13 June 2010, Number: 27610, Articles 1, 31 and 47.

Anonymous. (2010b). Law Regulating the Commerce of Fruits and Vegetables and Other Goods Enough Supply and Demand Level. Official Gazette of the Republic of Turkey, 26 March 2010, Number: 27533, Articles 1, 4, 17 18 and the first ad interim.

Anonymous. (2011). The Regulation on Appointment and Relocation of Forest Enforcement Officers, Forest Enforcement Officers. Official Gazette of the Republic of Turkey, 20 September 2011, Number: 29125, Article 12. 
Anonymous. (2016). Regulation Forests Regarding Special Forests and Authorized Public Institutions. Official Gazette of the Republic of Turkey, 05 May 2016, Number: 29702, Article 10.

Anonymous. (2018). The Presidential Decree No: 1 on the Organization of the Presidential. Official Gazette of the Republic of Turkey, 10 July 2018, Number: 30474, Articles 412 and 416.

APGC (Ankara Provincial Gendarmerie Command). (2021). Environmental Protection Teams and Their Duties. Retrieved on July 24, 2021 from https://ankara.jandarma.gov.tr/cevre-koruma-timleri

Arslan, M. (2018). Transition from law enforcement power approach into law enforcement service approach in administrative law enforcement activities. Journal of Erciyes University Faculty of Economics and Administrative Sciences, 52, 175-196. https://doi.org/10.18070/erciyesiibd.306669

Atalay, M. A. (2015). Fishing. Retrieved on July 24, 2021 from https://docplayer.biz.tr/29273806-Su-urunleri-avciligibalikcilik-ve-su-urunleri-genel-mudurlugu-avcilik-vekontrol-daire-baskani-dr-m-altug-atalay.html

BM (Beşiktaş Municipality). (2015). Fisheries Law No. 1380 Training. Retrieved on July 24, 2021 from https://besiktas.bel.tr/Sayfa/10002/1380-sayili-suurunleri-kanunu-egitimi

Boto, I., La Peccerella, C., Scalco, S., \& Tsamenyi, M. (2009). Fighting against Illegal, Unreported and Unregulated (IUU) fishing: Impacts and challenges for ACP countries. Brussels Rural Development Briefings A series of meetings on ACP-EU development issues, Briefing no. 10. Retrieved on July 24, 2021 from https://brusselsbriefings.files.wordpress.com/2012/10/r eader-br-10-iuu-fisheries-eng.pdf

ÇG (Çorum Governorate). (2019). In addition, trainings on Animal Breeding and Fisheries, Source of Life, Village Law No. 442 etc. were organized for the Neighborhood and Village Headmen by the Çorum Governorship (Training Program for Neighborhood and Village Headmen was Organized by our Governorship. Retrieved on July 24, 2021 from http://www.corum.gov.tr/valiligimiz-tarafindanmahalle-ve-koy-muhtarlarina-egitim-programiduzenlendi

CGC (Command of Coast Guard). (2021). Illegal Fishing. Retrieved on July 01, 2021 from https://www.sg.gov.tr/yasa-disi-su-urunleri-avciligi

CH (Chatham House). (2009). Fifth International Forum on Illegal, Unreported and Unregulated Fishing. Retrieved on July 24, 2021 from https://www.chathamhouse.org/sites/default/files/field/ field document/Meeting\%20Summary\%205th\%20Inte rnational\%20Forum\%20on\%20Illegal\%20Unreported\% 20and\%20Unregulated\%20Fishing.pdf

$\mathrm{CH}$ (Chatham House). (2018). Eleven International Forum on Illegal, Unreported and Unregulated Fishing. Retrieved on July 24, 2021 from https://www.chathamhouse.org/events/all/researchevent/11th-international-forum-illegal-unreportedand-unregulated-fishing

CH (Chatham House). (2020). Twelve International Forum on Illegal, Unreported and Unregulated Fishing. Retrieved on July 24, 2021 from https://www.chathamhouse.org/events/all/researchevent/12th-international-forum-illegal-unreportedand-unregulated-fishing

EC (European Commission). (2021). European Neighbourhood Policy and Enlargement Negotiations, Turkey. Retrieved on July 24, 2021 from https://ec.europa.eu/neighbourhoodenlargement/countries/detailed-countryinformation/turkey en

EU (European Union). (2011). Agreement on Port State Measures to Prevent, Deter and Eliminate IUU fishing. Official Journal of the European Union, 22 July 2011, L 191/3-18., Articles 5 and 17.

FAO. (2001). International Plan of Action to Prevent, Deter and Eliminate IUU Fishing. 25 p. Retrieved on July 24, 2021 from http://www.fao.org/3/y1224e/Y1224E.pdf

FAO. (2007). Report of the Global Fisheries Enforcement Training Workshop. FAO/FishCode Review No.18, FI/FCR18. Rome, Italy. 66pp.

FAO. (2008a). Report of the Second Global Fisheries Enforcement Training Workshop. FAO Fisheries and Aquaculture Report No. 885, FIIT/R885. Rome, Italy. $61 \mathrm{pp}$.

FAO. (2008b). FAO Regional Workshop on Port State Measures to Combat Illegal, Unreported and Unregulated Fishing. FAO Fisheries Report No. 859, FIEL/R859. Rome, Italy. $42 \mathrm{pp}$.

FAO. (2009). Agreement on Port State Measures to Prevent, Deter and Eliminate IUU Fishing, Articles 5 and 17. 
Retrieved on October 06, 2021 from http://www.fao.org/fileadmin/user upload/legal/docs/0 37t-e.pdf

FAO. (2017). Report of the Fifth Global Fisheries Enforcement Training Workshop. Series number: R1203. Rome, Italy. 159pp.

FAO. (2018). First PSMA inspectors' training course underway in the Port of Vigo. Retrieved on July 24, 2021 from http://www.fao.org/port-state-measures/newsevents/detail/en/c/1141795/

FAO. (2019). FAO continues ongoing capacity development work to implement the PSMA in Guinea. Retrieved on July 24, 2021 from http://www.fao.org/port-statemeasures/news-events/detail/en/c/1234375/

FAO. (2021). Agreement on Port State Measures to Prevent, Deter and Eliminate IUU Fishing. Retrieved on July 24, 2021 from http://www.fao.org/fileadmin/user upload/legal/docs/0 37s-e.pdf

FAO. (2021). Agreement on Port State Measures to Prevent, Deter and Eliminate IUU fishing, Article 17. Retrieved on July 24, 2021 from http://www.fao.org/fileadmin/user upload/legal/docs/0 $\underline{37 \mathrm{t}-\mathrm{e} . \mathrm{pdf}}$

FCWC (The Fisheries Committee for the West Central Gulf of Guinea). (2011). Sixth International Forum on Illegal, Unreported and Unregulated Fishing. Retrieved on July 24, 2021 from https://fcwc-fish.org/other-news/the-6thinternational-forum-on-illegal-unreported-andunregulated-iuu

GDS (The General Directorate of Security). (2021). The General Directorate of Security. Retrieved on July 24, 2021

from http://tr.wikipedia.org/wiki/Türkiye Cumhuriyeti Em niyet Genel Müdürlüğü

GFETW (Global Fisheries Enforcement Training Workshop). (2021). Its first virtual Global Fisheries Enforcement Training Workshop. Retrieved on July 24, 2021 from https://gfetw.org/

GGC (Gendarmerie General Command). (2021). Gendarmerie Environmental Protection Teams. Retrieved on July 24, 2021 from https://www.jandarma.gov.tr/asayis/jandarma-cevrekoruma-timleri

Göktürk, D., \& Deniz, T. (2017). Illegal, unreported, and unregulated fishing in Turkey: Effects on marine ecosystem and sustainable fisheries (pp. 2629-2638) In
Arapgirlioglu, H., Atik, A., Elliott, R., Turgeon, E. (Eds.), Researches on Science and Art in 21st Century Turkey (volume 2). Gece Publishing.

Grant, S. (2010). Regional Action Plans, Caribbean Rfu: Belize. Belize City, Belize, ACP FISH II, 38p.

HC (www.haberler.com). (2010). Inspection of Tirıvirı. Retrieved on July 06, 2021 from http://www.haberler.com/sivas-ta-tiriviri-denetimiyapildi-2105227-haberi/

HC (www.haberler.com). (2014). Inspection of Tirıvirı. Retrieved on July 06, 2021 from https://www.haberler.com/sivas-ta-4-bin-732-tiriviriele-gecirildi-6294759-haberi/

HC (www.haberler46.com.tr). (2015). Academic Fisheries Training for Marine. Retrieved on July 11, 2021 from https://www.haber46.com.tr/guncel/deniz-polisineakademik-su-urunleri-egitimi-h42857.html

HT (Habertürk). (2021). The Ministry of Trade will Recruit Enforcement Officers What are the Terms of the Ministry of Trade Enforcement Officers Recruitment? Retrieved on October 07, 2021 from https://www.haberturk.com/ticaret-bakanligimuhafaza-memuru-alimi-yapacak-ticaret-bakanligimuhafaza-memuru-alimi-sartlari-neler-3138229ekonomi

IASFA (Istanbul Amateur and Sports Fishing Association). (2019a). Amateur Fisherman Inspection. Retrieved on July 06, 2021 from https://www.isobder.org/haberler/amator-balikcidenetimi/

IASFA (Istanbul Amateur and Sports Fishing Association). (2019b). Marine Police Provided Training Under the Fisheries Law No. 1380. Retrieved on July 11, 2021 from https://www.isobder.org/haberler/deniz-polisine-1380sayili-su-urunleri-kanunu-kapsaminda-egitim-verildi/

IPAFD (Izmir Provincial Agriculture and Forestry Directorate). (2015). Fisheries Fisheries Inspection Training Provided. Retrieved on July 11, 2021 from https://izmir.tarimorman.gov.tr/Haber/153/SuUrunleri-Avcilik-Denetimi-Egitimi-Verildi

ISPAFD (Istanbul Provincial Agriculture and Forestry Directorate). (2020). Illegal travel hunting inspection. Retrieved on July 03, 2021 from https://istanbul.tarimorman.gov.tr/Haber/1285/Yasadis i-Trol-Avciligi-Denetimi

ISPAFD (Istanbul Provincial Agriculture and Forestry Directorate). (2015). Fisheries Inspection Training 
Given to Şişli Police. Retrieved on July 24, 2021 from https://istanbul.tarimorman.gov.tr/Haber/246/Sisli-

Zabitasina-Su-Urunleri-Denetim-Egitimi-Verildi

IUUWatch. (2017). Ten International Forum on Illegal, Unreported and Unregulated Fishing. Retrieved on July 24, 2021 from http://www.iuuwatch.eu/2017/03/10thinternational-forum-illegal-unreported-unregulatedfishing-chatham-house/

KN (Kariyet.net). (2021). What is a Customs Enforcement Officer? Retrieved on October 07, 2021 from https://www.kariyer.net/pozisyonlar/gumruk+muhafaz a+memuru/nedir

Limitada, K. (2007). Southern and Eastern Africa Forum to Counter IUU-Fishing. Maputa, Mozambique, Meeting Proceedings Volume 1, 39 p.

MAF (Ministry of Agriculture and Forestry). (2021a). Ministry of Agriculture and Forestry, Units. Retrieved on July 24, 2021 from https://www.tarimorman.gov.tr/Sayfalar/TasraTeskilati . aspx

MAF (Ministry of Agriculture and Forestry). (2021b). Ministry of Agriculture and Forestry, In-service Training Programs. Retrieved on July 24, 2021 from https://www.tarimorman.gov.tr/Sayfalar/Detay.aspx?Sa $\mathrm{yfaId}=6$

MAFF-FGD (Ministry of Agriculture and Forestry, Forrest General Directorate). (1996). The Regulation on the Duties and Working Principles of Forest Enforcement Officers. Ministry approval dated 06 March 1996 and numbered 4. Retrieved on July 24, 2021 from https://www.ogm.gov.tr/tr/e-kutuphane$\underline{\text { sitesi/mevzuat- }}$ sitesi/Yonetmelikler/Orman\%20Muhafaza\%20Memurl ar\%C4\%B1\%20G\%C3\%B6rev\%20Ve\%20\%C3\%87al\%C 4\%B1\%C5\%9Fma\%20Esaslar\%C4\%B1\%20Hakk\%C4\% B1nda\%20Y\%C3\%B6netmelik.pdf.

MM (Maritime Magazine). (2021). Trawler gates and nets were confiscated in Marmara. Retrieved on July 03, 2021 from https://www.denizcilikdergisi.com/denizcilik-gundemhaberleri/marmarada-trol-kapilari-ile-aglari-elkonuldu/

Mobiha, A. (2010). Regional Action Plans, Pacific Rfu: Honiara, Solomon Islands. Honiara, Solomon Islands, ACP FISH II, 34p.

NFDS (Nordenfjeldske Development Services). (2016). Nine International Forum on Illegal, Unreported and
Unregulated Fishing. Retrieved on July 24, 2021 from https://nfds.info/news/9th-international-forum-onillegal-unreported-and-unregulated-fishing-atchatham-house/

Njifonjou, O. (2010). Regional Action Plans, Central Africa Rfu: Libreville, Gabon. Libreville - Gabon, ACP FISH II, $33 \mathrm{p}$.

Öztürk, B. (2013). Some remarks of illegal, unreported and unregulated (IUU) fishing in Turkish part of the Black Sea. Journal of the Black Sea/Mediterranean Environment, 19(2), 256-267.

Öztürk, B. (2015). Nature and extent of the illegal, unreported and unregulated (IUU) fishing in the Mediterranean Sea. Journal of the Black Sea/Mediterranean Environment, 21(1), 67-91.

Purvis, J., \& Mindjimba, K. (2010). Regional Action Plans, Eastern Africa Rfu: Kampala, Uganda. Nakasero Road, Kampala, UGANDA, ACP FISH II, 35p.

RTMT (The Republic of Turkey Ministry of Trade). (2021). The Republic of Turkey Ministry of Trade. Retrieved on October 07, 2021 from https://ticaret.gov.tr/

Sall, A. (2010). Regional Action Plans, Western Africa Rfu: Dakar, Senegal. Dakar, Senegal, ACP FISH II, 39pp.

Soydan, T., \& Ünal, M. (2019). Gümrük ve Ticaret Bakanliğı'nda aday gümrük muhafaza ve muayene memurlarına yönelik olarak gerçekleştirilen hizmetiçi eğitim çalışmalarının değerlendirilmesi [Evaluation of in-service training studies achieved in the Ministry of Customs and Trade for adoptional customs enforcements and customs inspection members]. Milli Eğitim, 48(223), 361-378.

Tarabusi, L. (2010). Regional Action Plans, Southern Africa Rfu: Maputo, Mozambique. Maputa, Mozambique, ACP FISH II, 38pp.

Tuna-org. (2011). Report of the Workshop on Capacity Building of Developing States for Port State Measures and Catch Documentation Schemes. Seoul, Korea. 7 pp.

Wirajuda, S., Long, T., Wirajuda, H., As, H. V., Bergh, P. E., Brett, A., Copeland, D., Fernandez, M., Gusman, A., Juwana, S., Ruchimat, T., Trent, S., \& Wilcox, C. (2019). Illegal, unreported and unregulated fishing and associated drivers. Washington, DC: World Resources Institute. Retrieved on July 24, 2021 from https://oceanpanel.org/sites/default/files/202002/HLP\%20Blue\%20Paper\%20on\%20IUU\%20Fishing \%20and\%20Associated\%20Drivers.pdf 